\title{
KEANEKARAGAMAN MAKROZOOBENTOS DI PESISIR PANTAI DESA PANGGUNG KECAMATAN KEDUNG KABUPATEN JEPARA
}

\author{
Nisrina Arifatul Izzah, Efri Roziaty \\ Prodi Pendidikan Biologi FKIP Universitas Muhammadiyah Surakarta \\ Jl. A. Yani Tromol Pos 1 Pabelan Kartasura Surakarta, 57162 \\ Email: er375@ums.ac.id
}

\begin{abstract}
This research was about the macrozoobenthos diversity in Panggung beach, Kedung, Jepara conducted in March until April 2016. The purpose of this research was to investigated the rate of diversity macrozoobenthos. This research was using purposive sampling to determine the location and using line transect to determine plots. There were two main station 1 and stations named station I and station II. The study found 6 species consist of 2 species Bivalvia class (Phyllum Mollusca), they were Anadara granosa dan Scrobicularia plana, 2 Species Gastropoda (Phyllum Mollusca), they were Turritella nivea and Quoyia decollata, 1 from Crustacea (Phyllum Arthropoda) it was Penaeus indicus and 1 from Polychaeta Class (Phyllum Annelida) it was Arenicola marina. Species composition,c population density, diversity and evenness of species macrozoobenthos comunities in the station 1 higher than station 2. The result of analyze founded Indeks of diversity $\left(H^{\prime}\right)$ macrozoobentos in station I $(1,52)$ and station II $(1,47)$. Both stations showed the result $1<H<2$ indenticate low diversity and the quality of sea water environment a half polluted. The environmental quality of sea in seashore around Panggung beach,Kedunng Jepara needs attention to reduce the impact of environmental pollution.
\end{abstract}

Keywords: diversity, macrozoobenthos, panggung village

\begin{abstract}
Abstrak
Penelitian tentang Penelitian ini tentang keanekaragaman makrozoobentos di pesisir pantai Desa Panggung Kecamatan Kedung Kabupaten Jepara yang dilaksanakan pada Maret - April 2016. Tujuan penelitian ini adalah untuk mengetahui keanekaragaman makrozoobentos. Penelitian ini menggunakan metode purposive sampling dalam penentuan lokasi stasiun penelitian dan pembuatan plot mengunakan metode line transect. Stasiun penelitian terdiri dari dua stasiun yakni Stasiun I dan Stasiun II. Hasil Penelitian di temukan 6 spesies makrozoobentos terdiri dari 2 jenis dari Classis Bivalvia (Fillum Mollusca) yaitu spesies Anadara granosa dan Scrobicularia plana, 2 jenis dari Classis Gastropoda (Fillum Mollusca) yaitu spesies Turritella nivea dan Quoyia decollata, 1 jenis dari classis Crustacea (Fillum Arthropoda) yaitu Penaeus indicus, dan 1 jenis dari Classis Polychaeta (Fillum Annelida) yaitu Arenicola marina. Komposisi spesies, kepadatan populasi, kenanekaragaman dan keseragaman dari komunitas makrozoobentos bahwa stasiun I lebih tinggi dari stasiun II. Terlihat pada hasil indeks keanekaragaman $\left(\mathrm{H}^{\prime}\right)$ makrozoobentos di stasiun I $(1,52)$ dan stasiun II $(1,47)$. Kedua stasiun mengindikasikan bahwa keanekaragaman rendah dan kondisi kualitas lingkungan perairan dalam keadaan setengah tercemar. kualitas perairan laut di sekitar pesisir pantai desa Panggung kecamatan Kedung kabupaten Jepara membutuhkan perhatian untuk mengurangi pencemaran lingkungan.
\end{abstract}

Kata kunci: keanekaragaman, makrozoobentos, desa penggung

\section{PENDAHULUAN}

Perairan pesisir Jepara merupakan daerah intertidal, dimana daerah itu merupakan zona dangkal dari samudra yang bersisian dengan daratan dan terletak di antara garis pasang naik dan pasang surut (Mardianto,2014). Air laut merupakan komponen penting dalam komoditi lingkungan kawasan pesisir pantai. Aktivitas manusia dengan adanya pertumbuhan dan populasi yang tinggi di kawasan pesisir menimbulkan 
permasalahan bagi kelestarian lingkungan hidup. Kawasan pesisir pantai merupakan tempat bertemunya daratan dan air laut. Kawasan pesisir dan laut di Indonesia memegang peranan penting, kawasan pesisir memiliki nilai strategis berupa potensi sumberdaya alam danjasajasa lingkungan yang disebut sumberdaya pesisir. Sumber daya kawasan pesisir pantai merupakan lahan industri yangmampumeningkatkan pertumbuhan ekonomi di Indonesia (Marpaung, 2013).

Kawasan pesisir pantai sekarang ini sering di jadikan lahan industri seperti kawasan pesisir di daerah Jepara tepatnya di Desa Panggung Kecamatan Kedung yang kawasan pesisirnya merupakan tambak penghasil garam. Menurut Mardianto (2014) pengusahaan area lahan tambak garam di kembangkan di wilayah kecamatan Kedung salah satu daerah pengusahaan area tambak yaitu desaPanggung. Tambakgarammerupakan kegiatan industial yang mampu di unggulkan sebagai pengembangan lahan di sepanjang pesisir pantai wilayah pesisir kabupaten Jepara. Pengembangan lahan tambak garam memungkinkan terjadinya pencemaran dan kepunahan biota laut serta rusaknya ekosistem pesisir di sekitar pesisir pantai Desa Panggung, Kecamatan Kedung, Kabupaten Jepara.

\section{METODE PENELITIAN}

Pengambilan sampel makrozoobentos di laksanakan di perairan laut sekitar pesisir pantai desa Panggung kecamatan Kedung kabupaten Jepara yang di bagi menjadi dua stasiun yaitu stasiun I (daerah pesisir yang jauh dari tambak garam) dan stasiun II (daerah pesisir yang dekat dengan tambak garam), setiap stasiun terdiridarilimasubstasiununtukmewakili stasiun penelitian. Penentuan stasiun dilakukan secara Purposive Sampling Method (penempatan titik sampel dengan teknik survei). Penelitian dilaksanakan bulan Maret sampai April 2016. Jenis Penelitian ini adalah eksploratif kuantitatif. Jenis data yang diambil adalah 1) Data Makrozoobentos meliputi Kelas, Ordo, Familia, Genus dan Spesies yang didapatkan di perairan laut sekitar pesisir pantai desa Panggung. 2) Data habitat, meliputi: Tanggal dan waktu pengambilan data, nama lokasi, suhu air laut, salinitas air laut, $\mathrm{pH}$ air laut dan DO air laut. Analisis data meliputi a) perhitungan Kepadatan Populasi (KP). b) perhitungan Indeks Keanekaragaman. c) perhitungan Indeks Keseragaman Krebs (E).

\section{HASIL DAN PEMBAHASAN}

Faktor Abiotik di Pesisir Pantai Desa Panggung Kecamatan Kedung Kabupaten Jepara

Hasil pengukuran terhadap faktor abiotik sekitar pesisir pantai Desa Panggung Kecamatan Kedung Kabupaten Jepara pada Tabel 1, dibawah ini:

Tabel 1. Faktor Abiotik Pesisir Pantai Desa Panggung Kecamatan Kedung Kabupaten Jepara

\begin{tabular}{lll}
\hline Parameter & Stasiun I & Stasiun II \\
\hline FISIKA & & \\
Suhu $\left({ }^{\circ} \mathrm{C}\right)$ & $28-30$ & $30-32$ \\
Salinitas $(\%)$ & $30-31$ & $31-32$ \\
Sedimen & Lempung liat berpasir & Lempung berpasir \\
KIMIA & & \\
pH & $6.5-6.8$ & $6-6.5$ \\
DO $(\mathrm{mg} / \mathrm{L})$ & $3.8-4$ & $2.6-3$ \\
\hline
\end{tabular}


Berdasarkan tabel 1 faktor abiotik perairan berupa suhu perairan terlihat bahwa kondisi suhu perairan di laut pada rentang $28-32{ }^{\circ} \mathrm{C}$ yang di ukur menggunakan thermometer. Pada stasiun I suhu perairan berkisar 28-30 ${ }^{\circ} \mathrm{C}$ dan stasiun II suhu perairan berkisar 30-32 ○ C. Menurut Ihlas (2001) menyatakan bahwa suhu yang di tolerir untuk makrozoobentos berakomodasi terhadap lingkungannya berkisar antara $25-53^{\circ} \mathrm{C}$. Sedangkan menurut hasil penelitian Zahidin (2008) menyatakan bahwa suhu perairan yang optimal untuk pertumbuhan hewan-hewan makrozoobentos berkisar antara $25-35^{\circ} \mathrm{C}$. Hewan-hewan makrozoobentos mampu beradaptasi dengan suhuperairan di pesisir pantai Desa Panggung.

Berdasarkan tebel 1 salinitas perairan terlihat bahwa kondisi salinitas perairan di laut pada rentang 30-32 $\%$ yang di ukur menggunakan refraktometer. Pada stasiun I salinitas perairan berkisar 30-31 \% dan stasiun II salinitas perairan berkisar $31-32 \%$. Menurut Mudjiman (1981) menyatakan bahwa kisaran salinitas yang dianggap layak bagi kehidupan makrozoobentos berkisar $15-45 \%$, karena pada perairan yang bersalinitas rendah maupun tinggi dapat ditemukan makrozoobentos seperti siput, cacing (Annelida) dan kerang-kerangan. Sedangkan menurut hasil penelitian Marpaung (2013) menyatakan bahwa kisaran salinitas yang terukur ini masih sesuai untuk pertumbuhan makrozoobentos. Secara umum kisaran salinitas yang didapatkan di lokasi penelitian untuk setiap stasiun penelitian cukup bervariasi dengan kisaran nilai antara 15-30 \%o. Hewan - hewan makrozoobentos mampu beradaptasi dengan salinitas perairan di Desa Panggung.
Berdasarkan tabel 4.1 faktor abiotik perairan berupa $\mathrm{pH}$ perairan terlihat bahwa kisaran $\mathrm{pH}$ perairan laut pada rentang 6-7 yang di ukur menggunakan $\mathrm{pH}$ meter. Pada stasiun I $\mathrm{pH}$ perairan berkisar $6,8-7$ dan stasiun II $\mathrm{pH}$ perairan berkisar 6-6,5. Menurut Effendi (2003) menyatakan sebagian besar biota akuatik sensitif terhadap perubahan. Organisme bentos menyukai nilai $\mathrm{pH}$ sekitar 7-8,5 pada lingkungan hidupnya, jika $\mathrm{pH}<7$ maka telah terjadi penurunan populasi hewanhewan bentos. Sedangkan menurut hasil penelitian Asry (2014) menyatakan hasil sampling komunitas makrozoobentos mampu hidup pada kisaran $\mathrm{pH}$ 7-8 . Kondisi pada stasiun I dan II memiliki angka $\mathrm{pH}<7$ mengindikasikan keadaan lingkungan pada stasiun I dan II terindikasi adanya pencemaran di pesisir pantai Desa Panggung.

DO (Dissolved Oxygen) yang artinya oksigen terlarut dalam perairan. Berdasarkan tabel 4.1 DO perairan atau oksigen terlarut dalam periran laut berkisar antara 2,6-4 yang di ukur menggunakan DO meter. Pada stasiun I DO perairan berkisar antara 3,8$4 \mathrm{mg} / \mathrm{l}$ dan stasiun II DO perairan berkisar antara 2,6-3 mg/l. Menurut Saparinto (2007) menyatakan bahwa kadar DO yang sangat dibutuhkan oleh makrozoobenthos berkisar 4,00-6,00 mg/l. Semakin besar kadar DO dalam suatu ekosistem, maka semakin baik pula kehidupan makrozoobenthos yang mendiaminya. Berdasarkan hasil penelitian Marpaung (2013) menyatakan bahwa kisaran DO perairan yang menunjang komunitas sampel makrozoobentos berkisar antara 4-6 mg/l. Nilai DO tersebut masih dalam kondisi normal untuk menunjang kehidupan makrozoobenthos. Kondisi pada sebagian plot stasiun I dan stasiun II 
memiliki angka $\mathrm{DO}<4$ mengindikasikan keadaan lingkungan pada sebagian stasiun I dan II terindikasi adanya penurunan angka kadar oksigen yang mengindikasikan pencemaran di pesisir pantai Desa Pangung.

Berdasarkan pengukuran faktor Abiotik perairan laut. Faktor Abiotik seperti suhu perairan dan salinitas pada kedua stasiun masih sangat menunjang komunitas makrozoobentos untuk hidup. Namun pada pengukuran faktor Abiotik perairan laut berupa $\mathrm{pH}$ dan DO perairan kedua stasiun mengindikasikan adanya cemaran dalam perairan di desa Panggung kecamatan Kedung kabupaten Jepara.

\section{Keanekaragaman Makrozoobentos}

Hasil pengukuran terhadap faktor abiotik sekitar pesisir pantai Desa Panggung Kecamatan Kedung Kabupaten Jepara terlihat pada Tabel 2, di bawah ini:

Tabel 2. Data Keanekaragaman Makrozoobentos di Pesisir Pantai Desa Panggung

\begin{tabular}{|c|c|c|c|c|c|c|}
\hline \multirow{2}{*}{ Kelas } & \multirow{2}{*}{ Ordo } & \multirow{2}{*}{ Familia } & \multirow{2}{*}{ Spesies } & \multicolumn{2}{|c|}{ Jumlah Spesies } & \multirow{2}{*}{$\mathbf{N}$} \\
\hline & & & & Stasiun I & Stasiun II & \\
\hline Polychaeta & Capitellida & Arenicolidae & Arenicola marina & 5 & 15 & 20 \\
\hline Bivalvia & Arcoida & Arcidae & Anadara granosa & 80 & 8 & 88 \\
\hline Bivalvia & Veneroida & Semelidae & $\begin{array}{l}\text { Scrobicularia } \\
\text { plana }\end{array}$ & 50 & 3 & 53 \\
\hline Gastropoda & Mesogastropoda & Turritellidae & Turritella nivea & 15 & 25 & 40 \\
\hline Gastropoda & Neotaenioglossa & Planaxidae & Quoyia decollate & 20 & 30 & 50 \\
\hline Crustacea & Decapoda & Penaide & Penaus indicus & 40 & 2 & 42 \\
\hline
\end{tabular}

Berdasarkan tabel 2 diperlihatkan bahwa makrozoobentos yang teridentifikasi sebanyak 6 spesies yang tersebar pada 2 stasiun. Keenam spesies makrozoobentos tersebut terdiri dari 2 jenis dari kelas Bivalvia (Fillum Mollusca), 2 jenis dari kelas Gastropoda (Fillum Mollusca), 1 jenis dari kelas Crustacea (Fillum Arthropoda) dan 1 jenis dari kelas Polychaeta (Fillum Annelida) dari 293 individu yang di temukan. Hasil penelitian berdasarkan jenis yang di temukan sesuai dengan pendapat Nybakken pada tahun 1992 dijelaskan bahwa komunitas hewan makrobenthos merupakan hewan dasar yang hidup di endapan dasar perairan, baik merayap, menggalilubangataumelekatkandiripada substrat (sessile). Kelompok organisme dominan yang menyusun makrofauna di dasar perairan biasanya terdiri dalam 4 kelompok: Kelas Polychaeta, Kelas
Crustacea, Kelas Bivalvia dan Kelas Gastropoda. Selain itu, berdasarkan hasil penelitian Zahidin (2008) kelompok Kelas yang di temukan terdiri dari 2 jenis dari kelas Gastropoda, 1 jenis dari kelas Crustacea, 3 jenis dari kelas Polychaeta dan 5 jenis dari kelas Bivalvia dari 300 individu yang di temukan.

Berdasarkan tabel 4.2 jenis individu makrozoobentos yang terbanyak yakni Kelas Bivalvia seperti kelompok spesies Anadara granosa dan Scrobicularia plana. Kelas Bivalvia merupakan kelompok hewan makrozoobentos yang paling sering di temukan, menurut Romimohtarto (2001) menjelaskan bahwa hewan-hewan kelas Pelecypoda (Bivalvia) hidup dengan cara menggali dan melekat langsung pada substrat. Ada dua cara untuk kelompok kelas ini melekat pada substrat yaitu dengan semen dan atau bahan seperti benang. 
Pelecypoda biasanya menyukai substrat yang halus berupa pasir berlumpur. Menurut Oemarjati (1990) menjelaskan bahwa Anadara granosa merupakan epibentos karena memiliki kemampuan menempel pada substrat dengan membentuk benang bisus. Selain itu, menurut penelitian Marpaung (2013) Kelas Pelecypoda (Bivalvia) kelompokmakrozoobentosdenganjumlah jenis terbesar yang di temukan dengan presentase $70 \%$ dari 1949 individu yang ditemukan.

Berdasarkan tabel 3 jenis individu makrozoobentos yang paling sedikit yakni Kelas Polychaeta yaitu spesies Arenicola marina. Kelas Polychaeta merupakanhewanyangsedikitditemukan seperti pada hasil penelitain Asry (2013) kelompok spesies Glycera sp. dan Arenicola marina (Polychaeta) merupakan jenis yang paling sedikit di temukan karena merupakan peliang pasir yang dalam sehingga sulit untuk di temukan. Selain itu, hasil penelitian Widyastuti (2011) menjelaskan bahwa hewan-hewan peliang seperti spesies Arenicola marina merupakan hewan makrozoobentos dengan jumlah terrendah. Menurut Nybakken (1992) genus Arenicola merupakan kelompok Polychaeta pemakan deposit. Arenicola makan dengan cara menggali substrat, mencerna dan menyerap bahan organik (atau bakteri) dan mengeluarkan bahan sisa melalui Anus. Arenicola marina menggali saluran berbentuk $U$ dalam sedimen serta bertahan dalam puluhan kilometer dalam kedalaman sedimen.

Berdasarkan Tabel 2 diperlihatkan bahwa makrozoobentos yang teridentifikasi sebanyak 6 spesies yang tersebar pada 2 stasiun. Keenam spesies makrozoobentos tersebut terdiri dari 2 jenis dari kelas Bivalvia (Fillum Mollusca), 2 jenis dari kelas Gastropoda (Fillum Mollusca), 1 jenis dari kelas Crustacea (Fillum Arthropoda) dan 1 jenis dari kelas Polychaeta (Fillum Annelida) dari 293 individu yang di temukan, berdasarkan jenis dan jumlah yang ditemukan lebih sedikit dari jenis serta jumlah yang di temukan pada penelitian tentang makrozoobentos sebelumnya. Menurut hasil penelitain Fikri (2014) pada pantai desa Kartika Jaya kecamatan Patebon kabupaten Kendal variasi makrozoobentos yang di temukan yaitu terdiri dari Kelas Crustacea, Kelas Bivalvia dan Kelas Gastropoda. Komunitas terdiri dari 11 jenis dari kelas Gastropoda, 2 jenis dari kelas Bivalvia dan 2 jenis dari kelas Crustacea dari 842 individu yang ditemukan, selain itu menurut hasil penelitian Asry (2013) pada pantai kecamatan Pantai Labu kabupaten Deli Serdang menyatakan bahwa makrozoobentos yang diidentifikasi dalam penelitian ini terdiri atas 5 kelas yaitu: Crustacea terdiri atas 7 spesies, Polychaeta terdiri atas 1 spesies, Bivalvia terdiri atas 3 spesies, Gastropoda terdiri atas 25 spesies dari 2052 individu. Berdasarkan beberapa penelitian dia atas dapat di lihat bahwa jumlah angka jenis makrozoobentos yang di temukan di pesisir pantai Desa Panggung sangat sedikit.

Jenis dan jumlah spesies yang ditemukan sedikit berpengaruh pada kepadatan populasi, indeks keanekaragaman serta keseragaman. Hasil rekap kepadatan populasi, indeks keseragaman dan keanekaragaman ditunjukkan pada Tabel 3. 
Tabel 3. Rekapitulasi Perhitungan Kepadatan Populasi, Keanekaragaman, dan Keseragaman Makrozoobentos di Pesisir Pantai Desa Panggung

\begin{tabular}{llllllll}
\hline \multirow{2}{*}{ No } & \multicolumn{2}{c}{ Spesies } & \multicolumn{3}{c}{ Stasiun I } & \multicolumn{3}{c}{ Stasiun II } \\
\cline { 3 - 7 } & & $\mathbf{K P}$ & $\mathbf{H}^{\prime}$ & $\mathbf{E}^{\prime}$ & $\mathbf{K P}$ & $\mathbf{H}^{\prime}$ & $\mathbf{E}^{\prime}$ \\
\hline 1 & Arenicola marina & 0.02 & & & 0.07 & & \\
2 & Anadara granosa & 0.36 & & & 0.04 & & \\
3 & Scrobicularia plana & 0.22 & 1.52 & & 0.02 & 1.47 & \\
4 & Turritella nivea & 0.06 & & 0.85 & 0.11 & & 0.82 \\
5 & Quoyia decollate & 0.09 & & & 0.13 & & \\
6 & Penaus indicus & 0.18 & & & 0.01 & & \\
\hline
\end{tabular}

Berdasarkan tabel 3 diatas Kepadatan Populasi antara stasiun I dan II berbeda, kepadatan populasi pada stasiun I berkisar 0,02 - 0,36, sedangkan pada stasiun II kepadatan populasi berkisar 0,01 - 0,13. Stasiun I spesies yang memiliki angka kepadatan populasi tertinggi adalah spesies Anadara granosa dengan angka 0,36, sedangkan yang memiliki angka kepadatan populasi terrendah adalah spesies Arenicola marina dengan angka 0,02. Berdasarkan hasil penelitian Islami (2013) menyatakan bahwa komunitas kelas Bivalvia memiliki rentang toleransi terhadap lingkungan. Kondisi lingkungan perairan yang sesuai dengan taraf hidup bivalvia yakni 24$31^{\circ} \mathrm{C}$ dan 15-35 \%o dengan keadaan sedimen dasar perairan laut berupa sedimen berlumpur liat hingga berpasir. Pada stasiun II Spesies yang memiliki angkakepadatan populasitertinggiadalah spesies Quoyia decollata dengan angka 0,13 , sedangkan yang memiliki angka kepadatan populasi terrendah adalah spesies Penaeus indicus dengan angka 0,01. Menurut Asry (2013) menyatakan bahwa Gastropoda adalah kelas yang paling sukses dan mempunyai penyebaran yang sangat luas, mulai dari wilayah pasang surut sampai pada kedalaman $8.200 \mathrm{~m}$ dan mempunyai kemampuan beradaptasi terhadap kekeringan dan perubahan salinitas serta derajat keasaman $(\mathrm{pH})$ dari tanah akibat pengaruh air laut dan air tawar. Berdasarkan hasil terlihat terlihat stasiun I memiliki jumlah angka kepadatan populasi yang lebih tinggi dari stasiun II di bandingkan dengan jumlah angka kepadatan populasi antar stasiun, stasiun I berkisar antara 0,02-0,36 sedangkan stasiun II berkisar antara 0,01 0,13 dapat di artikan bahwa kepadatan populasi yang signifikan terdapat di stasiun I.

Berdasarkan tabel 3 di atas perhitungan Indeks Keanekaragaman dan Indeks Keseragaman pada stasiun I dan II memiliki perbedaan angka hasil dalam indeks keanekaragaman dan keseragaman. Pada stasiun I indeks keanekaragaman dan keseragaman yaitu $\mathrm{H}^{\prime}$ sekitar 1,52 dan $\mathrm{E}^{\prime}$ sekitar 0,85. Indeks keanekaragaman pada stasiun I bisa di kategorikan memiliki keanekaragaman rendah namun kualitas perairan setengah tercemar karena menurut persamaan Shanon-Wiener $\mathrm{H}^{\prime}$ terdapat pada kisaran $1-2$, sedangkan indeks keseragaman dapat di artikan bahwa keseragaman tinggi menurut persamaan Krebs karena E' pada stasiun I berkisar antara 0,6-1. Pada stasiun II indeks keanekaragaman dan keseragaman yaitu $\mathrm{H}^{\prime}$ sekitar 1,47 dan $\mathrm{E}^{\prime}$ sekitar 0,82. Indeks keanekaragaman pada stasiun II bisa di kategorikan memiliki keanekaragaman rendah namun kualitas periran setengah tercemar, sedangkan indeks keseragaman dapat di artikan bahwa keseragaman tinggi 
karena $E^{\prime}$ pada stasiun II berkisar antara 0,6-1. Menurut Lee, dkk (1975) dalam Fachrul(2007)menyatakanbahwakategori Indeks keanekaragaman berdasarkan persamaan Shanon-Wiener dinyatakan sangat tinggi dan tidak tercemar berkisar $>3$, tinggi dan tercemar ringan berkisar antara $2-3$, rendah dan setengah tercemar berkisar antara $1-2$, sangat rendah dan tercemar berat berkisar $<1$. Menurut Odum (1993) menyatakan bahwa indeks keseragaman Krebs (E') berkisar 0-1. Bila nilai mendekati 0 berarti keseragaman rendah karena adanya jenis lain yang sangat mendominasi, dan bila mendekati 1 berarti keseragaman tinggi karena menunjukkan bahwa tidak ada jenis yang mendominasi pada habitat tersebut. Menurut Indriyanto (2010) menyatakan bahwa indeks keanekaragaman dan keseragaman memiliki keterkaitan. angka indeks keanekaragaman $\left(\mathrm{H}^{\prime}\right)$ yang semakin tinggi memungkinkan terjadinya angka indeks keseragaman rendah karena keragaman dalam setiap komunitas baik secara genetik dan jenis dalam suatu habitat berbeda serta tidak seragam. Berdasarkan hasil dari tabel 3 di perlihatkan bahwa $\mathrm{H}^{\prime}$ sekitar 1,47 - 1,52 dan E'0,82-0,85 memperlihatkan bahwa keanekaragaman makrozoobentos diDesa Panggung rendah dan keseragamannya tinggi.

\section{PENUTUP}

\section{Simpulan}

Dari hasil penelitian terhadap keanekaragaman makrozoobentos di pesisir desa Panggung kecamatan Kedung kabupaten Jepara di dapatkan kesimpulan bahwa:

Faktor Abiotik berupa suhu dan salinitas yaitu suhu $28-32^{\circ} \mathrm{C}$ dan salinitas 30 - 32\% masih normal untuk kehidupan sedangkan berupa $\mathrm{pH}$ dan $\mathrm{DO}$ yaitu $\mathrm{pH}$ $<7$ dan DO 2,6 - 4 tidak dalam kondisi normal untuk kehidupan makrozoobentos yang mengindikasikan adanya pencemaran secara kimiawi. Jenis komunitas makrozoobentos di perairan laut desa Panggung ditemukan 6 spesies makrozoobentos terdiri dari 2 jenis dari kelas Bivalvia (Fillum Mollusca) yaitu spesies Anadara granosa dan Scrobicularia plana, 2 jenis dari kelas Gastropoda (Fillum Mollusca) yaitu spesies Turritella nivea dan Quoyia decollata, 1 jenis dari kelas Crustacea (Fillum Arthropoda) yaitu spesies Penaeus indicus dan 1 jenis dari kelas Polychaeta (Fillum Annelida) yaitu spesies Arenicola marina. Kepadatan Populasi di stasiun I berkisar 0,02 - 0,36 dan stasiun II 0,01 - 0,13 kepadatan populasi yang signifikan terdapat di stasiun I. Keanekaragaman $\left(\mathrm{H}^{\prime}\right)$ makrozoobentos di stasiun I $(1,52)$ dan stasiun II $(1,47)$, ,kedua stasiun menunjukkan hasil $1<$ $\mathrm{H}<2$ mengindikasikan bahwa keanekaragaman rendah dan kondisi klingkungan perairan di pesisir pantai Desa Panggung di indikasikan dalam keadaan setengah tercemar. Keseragaman (E') makrozoobentos di stasiun I $(0,85)$ dan stasiun II $(0,82)$ kedua stasiun menunjukkan hasil $0,6<\mathrm{H}<1$ mengindikasikanbahwakeseragaman tinggi serta tidak ada jenis yang mendominasi.

\section{Saran}

Berdasarkan hasil penelitian, saran yang dapat disampaikan pelaksana yaitu: Penelitian ini sebaiknya dilakukan pada musim kemarau dan kondisi air pasang untuk mengurangi faktor abiotik 
yang menyebabkan terganggunya spesies makrozoobentos. Perlu dilakukan pengukuran kualitas perairan lebih akurat baik secara Fisika maupun kimia dengan mengukur arus, kecerahan, kekeruhan, sedimen, COD, BOD, kandungan mineral air laut. Untuk metode penelitian selanjutnya hendaknya dibuat zona-zona area pengambilan sampel.

\section{UCAPAN TERIMAKASIH}

Peneliti mengucapkan terima kasih kepada kepala Desa Panggung, kepala Kecamatan Kedung, kepala Dinas Kelautan dan Perikanan Kabupaten Jepara yang telah memberi izin untuk penelitian dan membantu jalannya penelitian dengan data yang diberiuntukmenunjang pengkajian kualitas air laut melalui keanekaragaman makrozoobentos di pesisir pantai desa Panggung kecamatan Kedung kabupaten Jepara.

\section{DAFTAR PUSTAKA}

Arief, A. M. (2003). Hutan Mangrove Fungsi dan Manfaatnya. Yogyakarta: Kanisius. Asry, A., Yunasfi, \& Harahap, Z. A. (2014). Komunitas Makrozoobentos Sebagai Bioindikator Kualitas Perairan Kecamatan PantaiLabu Kabupaten Deli Serdang. Medan: Universitas Sumatera Utara.

Effendi, H. (2003). Telaah Kualitas Air. Yogyakarta: PT. Kanisius. Fachrul, M. F. (2012). Metode Sampling Bioekologi. Jakarta: Bumi Aksara. Ihlas. (2001). Struktur Komunitas Makrozoobentos Pada Ekosistem Hutan Mangrove di Pulau Sarapa
Kecamatan Liukang Tupabiring Kabupaten Pangkap Sulawesi Selatan. Aqua marine, 35-42. Indriyanto. (2010). Ekologi Hutan. Jakarta: Bumi Aksara.

Islami, M. M. (2013). Pengaruh Suhu dan Salinitas Terhadap Bivalvia. Oseana, 1-10.

Mardianto, D. (2014). Potensi Sumberdaya Pesisir Kabupaten Jepara. Yogyakarta: Gadjah Mada University Press.

Marpaung, A. A. (2013). Keanekaragaman Makrozoobenthos Di Ekosistem Mangrove Silvofishery Dan Mangrove Alami Kawasan Ekowisata Pantai Boe Kecamatan Galesong Kabupaten Takalar. Makasar: Universitas Hasanuddin Makasar.

Marwah, S. (2007). Daerah Aliran Sungai (DAS) Sebagai Satuan Unit Perencanaan Pembangunan Pertanian Lahan Kering Berkelanjutan. Bogor: Institut Pertanian Bogor.

Mudjiman. (1981). Budidaya Udang - Udangan. Jakarta: PT. Penebar Swadaya. Nybakken, J. W. (1992). Biologi Laut Suatu Pendekatan Ekologis. Jakarta: PT. Gramedia Pustaka Utama. Odum, E. P. (1993). Dasar-Dasar Ekologi Umum. Yogyakarta: Gadjah Mada University Press.

Oemarjati, B. S., \& Wisnu, W. (1990). Taksonomi Avertebrata. Jakarta: UI press. Rahayu, A. C. (2007). Keanekaragaman Mollusca Bercangkang (Gastropoda dan Pelecypoda) Di Daerah Pantai Tirta Samudra Kabupaten Jepara. Surakarta: Universitas Muhammadiyah Surakarta. 
Romimohtarto, K., \& Juwana, S. (2001). Biologi Laut : Ilmu Pengetahuan Tentang Biota Laut. Jakarta: Djambatan.

Subiyanto, W. P., \& Muskananfola, M. R. (2014). Kelimpahan Krustasea Berdasarkan Fase Bulan Di Perairan Pantai Jepara. DIPONEGORO JOURNAL OF MAQUARES,188-196.

Suryanto, \& Utojo. (1993). Avertebrata Air Jilid 1. Jakarta: Swadaya.

Widyastuti, A. (2011). Struktur Komunitas Makrozoobentos di Perairan Biak Selatan, Biak, Papua. Biak: UPT Loka Konservasi Biota Laut Biak- LIPI.

Wilhm, J. F. (1975). Biological Indicator of Pollution. London: Blackwell Scientific Publications.

Zahidin, M. (2008). Kajian Kualitas Air Di Muara Sungai Pekalongan Ditinjau Dari Indeks Keanekaragaman Makrobenthos Dan Indeks Saprobitas Plankton. Semarang: Universitas Diponegoro. 